\title{
Planned Obsolescence: A Strategy in Search of Legal Rules
}

\author{
Mariateresa Maggiolino
}

One might think - perhaps naively - that the life span of a product depends on uncontrolled factors such as fate or the wear and tear of its materials. As a matter of fact, the truth is that it is often the result of entrepreneurial choices. For example, it was 1924 when the major light bulb producers of the time, including Philips, General Electric and Osram, agreed to cut in half their incandescent bulbs' lifetime, with the ultimate effect of keeping unchanged the sales volume of new light bulbs. Again, it was the 1950s when, across the Atlantic Ocean, the "Throw-Away Society" was conceived of as a production system where companies would preserve high sales volumes by using advertising campaigns to instill in consumers the desire to own something "a little newer, a little better, a little sooner than is necessary". 1 More recently, it is well understood that a company that produces durable goods from household appliances to mobile phones - can act, even unilaterally, to degrade their products' performance and thereby induce their replacement. Typically, a firm can design a durable good for it to fail prematurely or to prevent it from being used beyond a predetermined number of times. Likewise, by acting on the price, characteristics, or technological compatibility of spare parts, a company can make it more convenient for consumers to replace the product rather than to repair it. ${ }^{2}$

In summary, companies can resort to a wide variety of conducts to program the life span of their products and to impose their replacement prematurely. All these business practices serve to produce a strategy that falls under the term of "planned obsolescence".

\footnotetext{
1 Glenn Adamson and David Gordon (2003), Industrial Strength Design: How Brooks Stevens Shaped Your World, Cambridge, MIT Press, pp. 4-5.

2 BEUC (the European Consumer Organisation), "More sustainable products, better consumer rights", 2015 available at https://www.beuc.eu/publications/beuc-x-2015-069_sma_upa_beuc_position_paper_ durable_goods_and_better_legal_guarantees.pdf (accessed 11 March 2018).
} 
In the economic literature, planned obsolescence has been the subject of many studies. ${ }^{3}$ In particular, alongside the several models that indicate the market conditions under which an enterprise finds optimal cannibalizing of a version of its durable good with another, there are numerous studies highlighting the positive and negative effects of launching the new versions of a product. On the one hand, planned obsolescence may lead to an increase in R\&D investments and in the rate of innovation made available to consumers. In addition, it can also support long-term economic growth. On the other hand, planned obsolescence may worsen consumer debt levels, increase their dissatisfaction with poor quality and short-lived products, and increase the waste of natural resources. ${ }^{4}$

The legal classification of planned obsolescence is instead a less explored and debated issue. One might think that the current rules offer an adequate scope for deterring planned obsolescence. For example, and considering to the aforementioned example, it is true that antitrust rules are able to sanction two or more undertakings that, as in the case of incandescent light bulbs, reach an agreement aimed at worsening the quality of supply by suppressing the innovation that they could use to prolong the products' life span. However, the area of abuse of dominant position fails to capture the case of spare parts that worsen the performance of previous versions of the related durable good, if such spare parts are innovations that improve the functioning of the new versions of the same durable good. Furthermore, the legal rules governing unfair commercial practices do not allow the repression of planned obsolescence as such. Two recent proceedings concluded by the Italian Competition Authority (AGCM) in the Apple and Samsung cases, involved consumers who were induced to replace their smartphones, which had become almost unusable due to the installation of new updates of the respective operating systems. However, the AGCM did not punish the release of those updates. The AGCM considered as unfair, misleading and aggressive those practices aimed at persistently suggesting the updating of the smartphones' operating systems on the basis of information that concealed or mystified the impact that the said change would have on the performance of the smartphone, in particular on battery wear as well as practices aimed at not offering, subsequent to the installation of the update, any means of restoring the previous functionality of the units. ${ }^{5}$ In other words, if Apple and Samsung had been transparent and left consumers free to choose whether or not to replace their smartphones, then the obsolescence of those smartphones indirectly provided by the updates of their operating systems would not constitute illicit behavior.

\footnotetext{
3 See, in particular, Michael Waldman (1993), "A New Perspective on Planned Obsolescence", 108(1) The Quarterly Journal of Economics p. 273; Arthur Fishman, Neil Gandal and Oz Shy (1993), "Planned Obsolescence as an Engine of Technological Progress", 41 The Journal of Industrial Economics p. 361; and Jeremy Bulow (1986), “An Economic Theory of Planned Obsolescence, 101 The Quarterly Journal of Economics p. 729.

4 See, in particular, Neil Maycroft (2009), "Consumption, Planned Obsolescence and Waste", University of Lincoln Working Paper; and Joseph Guiltinan (2009), "Creative Destruction and Destructive Creation: Environmental Ethics and Planned Obsolescence", 89 Journal of Business Ethichs p. 19.
}

5 AGCM (Autorità Garante della Concorrenza e del Mercato), case No. PS11039, Apple, 25 September 2018; and AGCM, case No. PS11009, Samsung, 25 September 2018. 
Thus, these examples show that, up to now, the great majority of legal rules available to manage planned obsolescence only focus on the ways through which planned obsolescence is achieved.

At present, only in France, through Art. L213-4-1 introduced by the law 2015-992, does a rule exist defining planned obsolescence as "the set of techniques by which an issuer on the market aims to deliberately reduce the lifetime of a product in order to increase its replacement rate" 6 and qualifies this as a criminal offense punishable by a two-year prison sentence and a fine of up to $€ 300000$ or of up to $5 \%$ of the company's average turnover.

Similarly, it was only in 2017 that the European Parliament adopted a resolution (2016/2272 (INI)) inviting the Commission to

propose [...] a definition [...] of programmed obsolescence for tangible products and software; [...] examine the possibility of establishing an independent system able to test and detect the obsolescence embedded in products; [... and to provide for ...] better legal protection for so-called whistleblowers and appropriate dissuasive measures for producers. (Sec 30)

Furthermore, in the same resolution, the Parliament paid particular attention to the case of obsolescence caused by software updates, requiring inter alia:

greater transparency as regards upgrading, security updates and durability; [...] definition of [a] reasonable period of use; clear information on the compatibility of updates and upgrades with embedded operating systems provided to consumers; [...] that the indispensable software updates are reversible and accompanied by information on the consequences on the operation of the device and that the new essential software is compatible with the previous generation software; [... and ...] the modularity of the components, including the processor, through a standardization exercise, so as to ensure that the asset is always updated. (Secs. 37-40)

In summary, to be more effective in the fight against planned obsolescence, legislators should conceive of tools that make it possible to punish planned obsolescence directly, that is, regardless the specific practices used to deliberately reduce the life span of a product.

Publisher's Note Springer Nature remains neutral with regard to jurisdictional claims in published maps and institutional affiliations.

\footnotetext{
6 “L'ensemble des techniques par lesquelles un metteur sur le marché vise à réduire délibérément the durée de vie d'un produit pour en augmenter le taux de remplaceme."
} 